\title{
Indonesian Positive Law and Islamic Criminal Law: Which is the Most Comprehensive Regulation on Anti-Corruption?
}

\author{
Heni Hendrawati* \\ Department of Law, Universitas Muhammadiyah Magelang \\ PO box 56172, Magelang, Indonesia \\ Johny Krisnan \\ Department of Law, Universitas Muhammadiyah Magelang \\ PO box 56172, Magelang, Indonesia
}

The research is financed by Center of Research, Development, and Community Services (LP3M) Universitas Muhammadiyah Magelang

\section{Abstract}

Eradicating corruption is a big problem and focus activities in every country. At present, corruption is closely related to moral, individual and cultural problems. Indonesia as a country with the largest Muslim population in the world needs an offer of regulations that integrate Islamic criminal law on its regulations. This article compares corruption in Indonesian positive law with Islamic criminal law. The approach used in this study is a comparative approach that is analyzed qualitatively. The results showed significant differences in the definition of corruption and sanctions in Indonesian positive law and Islamic criminal law. It is strengthening the implementation and internalization of Islamic values (Islamic values), national culture (nation values) and education needed in the formulation of regulations to eradicate corruption. Law enforcement against corruption is inseparable from the role of the judge in giving decisions that are adjusted to the values of the nation's culture, the level of criminal acts and the effects of such corruption.

Keywords: Eradicating Corruption, Islamic Criminal Law, Indonesian Positive Law

DOI: $10.7176 / \mathrm{JLPG} / 85-10$

Publication date:May $31^{\text {st }} 2019$

\section{Introduction}

Corruption is no longer a problem related to structural, political or economic. Corruption is also closely related to moral, individual and cultural problems. At present, corruption is also a religious study, because religion is one of the best moral instructors (Ilyas, 2004). Baharuddin Lopa stated that the anti-corruption campaign must be returned to the path of religion and ethics, considering that corruption cases are increasing, because for the present the law is no longer able to prevent corruption practices (Lopa, 2001). This is also considering that Indonesia is a country with the world's largest Muslim population.

As al-din and al-daulah, Islam also regulates human relations with Allah and places ethical and moral bases in human relations with others (Suyitno, 2006). Islam has a clear concept in underlying the problem of assets; the origin of the assets obtained and the distribution of assets so that this is very contradictory to the Indonesian population which is predominantly Muslim.

Islam has provisions to obtain legitimate assets that do not have the elements of al-batil and al-zalim which are often in the form of theft (al-sariqah) and robbery (al-hirabah). Islam prohibits the acquisition of illegal assets and violates the provisions of Islamic law. However, along with the development of human civilization, criminal acts against property continued to develop using new terms, including corruption, money politics and money laundry.

Any form of corruption is included in the category of obtaining illegal assets according to Islam. This is due to the acquisition of assets with al-Batil and al-Zalim. Islam has legal provisions and sanctions for corruption practices. In the study of fiqh, forms of corruption can be found in terms of risywah (bribery, facilitation payments, bribes) and ghulul (betrayal, fraudsters, traitors). To answer the problem of corruption, Indonesian Muslims have reacted through a fatwa on corruption.

\section{Research Method}

This research was conducted by comparing criminal acts of corruption in positive criminal law and Islamic criminal law. In addition, verification was carried out with field research using interviews with experts in Islamic criminal law. The data were analyzed using a qualitative approach and presented in the descriptive form.

\section{Result and Discussion}

3.1. Corruption in the Positive Criminal Law Perspective

In Indonesia, the definition of corruption is explained in 13 articles in Law No. 31 of 1999 concerning Eradication 
of Criminal Corruption Crimes. Based on these articles, corruption is formulated in 30 types of corruption that are divided into seven groups, namely:

1. State Financial Losses

The formulation of corruption acts as referred to in Law Number 31 of 1999 concerning Eradication of Corruption Crimes is every person (individual or corporation) who fulfills the elements of article 2 paragraph (1) of the Law No. 31 of 1999 . Therefore, the perpetrators of corruption according to the article are "everyone" there is no obligation for Civil Servants.

Article 2 paragraph (1) of Law Number 31 of 1999 is;

a. Unlawfully;

b. Doing acts enriching oneself or others or corporations;

c. Harming the country's finances or the country's economy.

2. Bribery

a. Bribe public servants or state administrators

According to Article 5 paragraph (1) of Law 20 of 2001 regulates active bribery, which punishes every person (individual and corporation) who gives or promises something to civil servants or state administrators. Whereas Article 5 paragraph (2) regulates passive bribery, namely civil servants or state administrators, who receive gifts or promises. So not only the person who bribes is punished, but also the person who receives the bribe.

b. Judges Bribe and advocates

Article 6 of Law No. 20 of 2001 regulates bribery committed against judges and advocates. In paragraph (1) the article regulates active bribery, which prohibits any person (individual or corporation) from giving or promising something to a judge or advocate. While in paragraph (2) regulating passive bribery, the meaning in the provision prohibits judges or advocates who accept gifts or promises. The sentence is the same as the active bribery.

3. Embezzlement of position

The act of office fraud referred to in article 8 of Act No. 20 of 2001 is to intentionally embezzle money or securities held for his position, or allow the money or securities to be taken or darkened by others, or to help carry out such acts.

4. Extortion

The categories related to extortion are listed in Article 12 letter e, letter f, and letter g of Law No. 31 of 1999 jo. Law No. 20 of 2001:

a. Civil servants or state administrators with the intent to benefit themselves or others against the law, or by abusing their power forcing someone to give something, pay, or accept payment by piece, or to pursue something for themselves;

b. Civil servants or state administrators who at the time carry out their duties, request, receive, or deduct payments to civil servants or other state administrators or to the general cash, as if the public servants or other state administrators or the public cash have debts to them, even though it is known that this is not a debt;

c. Civil servants or state administrators who, when carrying out their duties, ask for or accept jobs, or hand over goods, as if they were a debt to themselves, even though it is known that this is not a debt;

5. Cheating

Article 7 paragraph (1) Law No. 20 of 2001 is regulated regarding active fraudulent acts. Actors according to the provisions of the paragraph are contractors, construction experts, people who oversee the construction or delivery of goods. Anyone who is delivering goods needs to the Indonesian National Army (TNI) or the National Police of the Republic of Indonesia (POLRI), or anyone in charge of overseeing the delivery of goods for TNI or POLRI. The actions which are prohibited in this verse are deceit, using false names. Article 7 Paragraph (2) Law No. 20 of 2001 threatens criminality against persons who receive the surrender of buildings or people who receive the surrender of goods for TNI or POLRI needs and that person allows fraudulent acts to occur. There are two articles included in the category of corruption related to fraudulent acts, namely Article 7 paragraph (1) letter a, letter b, letter c and letter d, and Article 7 paragraph (2) Law No. 31 of 1999 jo. Law No. 20 of 2001.

6. Conflict of Interest in Procurement

Corruption in the category of conflict of interest in procurement as stated in Article 12 letter i of Law No. 31 of 1999 jo. Law No. 20 of 2001: Civil servants or state administrators, both directly and indirectly, intentionally participate in chartering, procurement, or leasing, which at the time of the act, for all or part of them is assigned to manage or supervise it.

7. Gratification

Gratification is regulated in Article 12 B of Law No. 20 of 2001 which explains that gratification to civil servants or state administrators is considered giving bribes when related to his position and which is contrary 
to his obligations or duties.

\subsection{Corruption Crime in the Perspective of Islamic Criminal Law and Its Contribution to Renewal of National Criminal Law}

A crime of corruption in the perspective of Islamic criminal law is a criminal act of betraying state wealth (khiyānah) which has many levels and frequencies. Some terms as forms of actions that contain elements of corruption in the view of Islamic criminal law can be seen below:

1. Ghulul

This concept is often associated with corruption because it is seen as a form of betrayal of the mandate that should be maintained. Ghulul means to take something and hide it in his wealth. Ghulul is a term for embezzlement of spoils of war before being distributed. The term Ghulul can also be used for fraud in the field of government or fraud committed by an official. The reason is that the two forms of ghulul are manifestations of treasonous acts on the job and because the two forms of ghulul are forbidden because there is an element of harming others, both one person and the general public and the state for embezzlement or also receiving gifts that are not theirs.

2. Rishwah (Bribery)

Rishwah refers to the word rasha-yarshu-rishwah, which means al-ju'l which means wages, gifts or commissions. While rishwah (bribery) in terms of terminology is the act of giving assets and for example to cancel the rights of another party or obtain the property of another party.

3. Betrayed

In general, betrayal means not keeping promises. In the Qur'an Surat al-Anfal verse 27 has been explained about the prohibition of betraying the mandate of fellow humans, Allah and His Messenger: "O ye who believe, do not betray Allah and the Messenger (Muhammad) and (also) do not betray the messages entrusted to you, while you know."

4. Mukabarah and Ghasab

Mukabarah and Ghasab are other concepts that can be linked to corruption seen from those who have power. Ghasab according to language, which is "to take something from someone's hand through violence."

5. Sariqah (Theft)

Sariqah is another concept that is directly linked to corruption because it is popular as the concept of transferring rights to property against the law. Theft (sariqah) is the act of taking the other party's assets clandestinely without any prior mandate. The perpetrators of this crime were sentenced to hand cut, as stated in QS. al-Maidah 38: Men and women who steal, cut off both hands (as) revenge for what they do and as torment from God. And Allah is Mighty, Wise.

6. Intikab and iktilas

The next concept that is frequently mentioned in the books of fiqh is intikab and iktilas. Intikab is robbing or grabbing, and the iktilas is pickpocketing.

7. Akl-suht

Suht is the last concept that is close to corruption. Suht means something destructive and considered as something that is haram. Suht is mentioned in QS. al-Maidah 1: They are people who like to hear false news, eat a lot of wrong things. If they (the Jews) come to you (to ask for a verdict), then decide (the matter) between them, or turn away from them; if you turn away from them, they will not give harm to you at all. And if you judge them, then decide (the case) between them with justice, surely Allah loves those who are fair.

\subsection{An offer for National Criminal Law Reform in the Eradication of Corruption Crimes}

Criminal acts of corruption in the perspective of positive criminal law and Islamic criminal law have similarities and differences. Before discussing things that can be contributed in the context of reforming national criminal law, we will discuss the differences in corruption in positive criminal law and Islamic criminal law, so that differences will result in things that can be contributed to the reform of national criminal law.

The difference between positive criminal law and Islamic criminal law can be seen in terms of subjects and objects. In positive criminal law, there are two subjects of corruption, namely humans and corporations. Humans are divided into state officials and non-state officials. This provision is stated in article 1 of the Corruption Crime Act: every person who commits an act enriches himself or another person or a corporation that can harm the state's finance or the country's economy. Both if committing acts of corruption are threatened with sanctions.

Islamic criminal law only has human subjects. This relies on the information in the book of fiqh that what is subject to the law is only mukallaf people. In general, the fundamental differences from positive criminal law and Islamic criminal law on the details in each action are categorized as a form of corruption. In positive criminal law, corruption is categorized as a special crime. Whereas in Islamic criminal law, corruption is equated with theft and robbery. Islamic criminal law categorizes corruption only based on the words ghulul and risywah. The two terms are drawn into several categories of corruption. For example, the act risywah one of which is the gratification or 
money politics.

In terms of its object, Islamic criminal law has no minimum limit of corrupted assets and does not always constitute state assets but emphasizes the loss of state finances. Unlike the case with positive criminal law which states that the assets that are corrupted are state assets. The integration of Islamic criminal law to build national law is crucial. Islamic criminal law has a set of rules that cover aspects of life. However, to work on this, Islamic criminal law must be able to provide conformity with the characteristics and culture of Indonesia.

Positive criminal law categorizes corruption acts in detail; loss of state finance, bribery, embezzlement in office, extortion, fraudulent acts, conflicts of interest in procurement, and gratuities. Whereas in Islamic criminal law only divided into two main categories, namely ghulul and risywah. If the category according to Islamic criminal law is adapted to the positive criminal category, the one that includes ghulul is embezzlement in office, extortion, fraudulent acts, conflict of interests in procurement, while those included in the risywah are bribery and gratuity.

Corruption is a criminal offense against state wealth (khiyānah) which has many levels and frequencies. Ta'zīr criminal sanctions given by the authorities or judges should consider this. Wa'dh, beating (dharb), dismissal ('azl), imprisonment (sizn), crucifixion (shulb) can be imposed on corruptors with certain levels, as well as capital punishment can be sentenced to corruptors by the amount which is very detrimental and has an impact on the benefit of the people (ihdar mashalih al-ammah). Corruptors are equated (qiyās) with subversion actors because they threaten the benefit of the state and the people. Ta ${ }^{\text {' } z \bar{r}}$ with capital punishment sanctions can also be imposed on corruptors who commit crimes repeatedly after being punished many times more lightly.

\section{Conclusion}

The criminal acts of corruption in the perspective of Islamic criminal law are aligned with several concepts of jarimah namely ghulul, risywah, betrayed, sariqah, mukabarah / ghasab, intikab, and akl suht. The most appropriate concept for criminal acts of corruption and is considered to facilitate the settlement of sentences is the concept of ghulul (embezzlement) and rishwah (bribery), with sanctions ta'zir from imprisonment to the death penalty adjusted for the severity of the actions and effects of corruption committed. Ta'zīr criminal punishment given by the ruler or judge can be a reprimand (wa'dh), beating (dharb), dismissal ('azl), imprisonment (sizn) and even crucifixion (shulb) can be imposed on corruptors with certain levels, as well as capital punishment can be sentenced to corruptors with a number that is very detrimental and has an impact on the benefit of the masses (ihdar mashalih al-ammah).

\section{References}

Books

Abdurrachman Qadir, Zakat dalam Dimensi Mahdhah dan Sosial ,Jakarta: Raja Grafindo Persada, 1998

A. S. Burhan, Korupsi di Negeri Kaum Beragama, Jakarta: P3M dan Partnership, 2003

Baharuddin Lopa, Kejahatan Korupsi dan Penegakan Hukum, Jakarta: Penerbit Buku Kompas, 2001

Masdar F. Mas'udi, Syariat Islam tentang Status Uang Negara dan Peran Ulama, Yogyakarta: Gama Media, 2006

Muchotob Hamzah dan Subakir Saerozi, Suap dalam Pandangan Islam, Jakarta: Gema Insani Press,2001

Suyitno, Korupsi, Hukum, dan Moralitas Agama: Mewacanakan Fikih Antikorupsi, Yogyakarta: Gama Media, 2006

Yunahar Ilyas, Korupsi dalam Perspektif Agama-agama(Panduan untuk Pemuka Umat), Yogyakarta: P3M UMY, 2004

\section{Journals}

Arini Indika Arifin, Lex et Societatis, Januari-Maret 2015, Vol III/No.1, Tindak Pidana Korupsi Menurut Perspektif Hukum Pidana Islam

Arli Fauzi, DIH Jurnal Ilmu Hukum Pebruari 2013, Vol 9, No. 17, Telaah Yuridis tentang Tindak Pidana Korupsi Dalam Pengadaan Barang dan Jasa Pada Sekretariat DPRD Kabupaten Sidoarjo.

Nur Iqbal Mahfudh, Jurnal Agama Dan Hak Azazi Manusia, Mei 2017, Vol. 6 No : 2, Hukum Pidana Islam Tentang Korupsi

Patardo Yosua Andreas Naibaho, Purwoto, Pujiyono, Diponegoro Law Journal, Tahun 2016, Volume 5 Nomor 4, Kebijakan Hukum Pidana Dalam Upaya Meningkatkan Peran Serta Masyarakat Dalam Pencegahan Dan Pemberantasan Tindak Pidana Korupsi.

Ridwan, Kanun Jurnal Ilmu Hukum Desember 2014, No 64, Upaya Pencegahan Tindak Pidana Korupsi Melalui Peran Serta Masyarakat.

, Jurnal Dinamika Hukum, September 2012, Volume 12, No : 3, Peran Lembaga Pendidikan Dalam Pemberantasan Tindak Pidana Korupsi Di Indonesia.

\section{Regulation}

Law Number 31 of 1999 Concerning Eradication on Corruption Crimes 